\title{
Building and Blurring the Intimate Boundaries of Nation, Race and Geopolitics in a Suburb Neighbouring a UK Immigration Removal Centre
}

Charles Leddy-Owen

\begin{abstract}
Drawing on analysis of qualitative interviews with 25 residents of an affluent, highly militarised suburb neighbouring a British immigration detention centre, this article analyses how constructions of place and home interrelate with nationalist, racialised and geopolitical boundaries. The article begins by introducing the fieldwork site before discussing the centrality of feminist geopolitics frameworks to the subsequent data analysis. The findings sections demonstrate how the centre and its detainees are routinely obscured by participants in relation to a suburb portrayed as simply 'nice' and homely. Analysis suggests that the mundane, everyday practices discussed by participants conceal the formation of simultaneously global, local and intimate boundaries rooted in nationalist and geopolitical distinctions with militarised and colonial histories. These boundaries are, however, partially unobscured locally for participants in relation to questions evoking the prospect of more intimate connections with detainees, and it is only by disavowing anxieties raised by this prospect that the legitimacy of detention and feelings of homeliness can be justified affectively and ethically. The conclusion argues that these findings are important for studies of contemporary border controls, as the same nationalist and racialised structures underpinning detention regimes are fundamentally implicated in embodied and emplaced notions of suburban homeliness.
\end{abstract}

Key words: Place; Miltarism; Immigration detention; Race; Nationalism; Feminist Geopolitics.

\section{Introduction}

When viewing Haslar Immigration Removal Centre (IRC) and its surroundings, striking contrasts can be drawn between the removal centre with its high, forbidding fences, and the local residential area in which it is situated. The motivation for the present study came from this first impression following a visit to the highly militarised suburb known here as Southcreek, ${ }^{1}$ and from the subsequent realisation of the starkly racialised division of population either side of Haslar's looming fences. The study involved qualitative semi-structured interviews with 25 'white' residents of suburban

\footnotetext{
${ }^{1}$ This pseudonymisation is aimed at preventing the area's identification through an internet search-engine. Anonymising the fieldwork site entirely would be futile given its easily identifiable characteristics.
} 
Southcreek about their views of the area and the IRC within it, enabling an analysis of their constructions of place and the IRC in relation to race, nationalism, migration and militarism.

The findings sections below critically explore how the IRC and its detainees are routinely obscured by participants in relation to a suburb they portray as simply 'nice'. It will be demonstrated, through a refocusing of scale influenced by feminist geopolitics approaches, how nationalist, racialised and global boundaries are produced at simultaneously local and global levels through mundane, everyday practices. The banal everydayness of the centre's fences can however be disturbed for participants in relation to anxieties regarding the prospect of intimacy with detainees. These anxieties can disrupt both the legitimacy of detention and the homeliness, the 'niceness', of Southcreek affectively and ethically. This sense of unease is partially remedied for most participants by its disavowal in relation to the disembodying rationalities of nationalism. Complex, embodied and emplaced, emotions and disavowals relating to Haslar IRC, and underpinned by nationalist and racialised structures, are therefore found to be fundamentally implicated in participants' constructions of suburban homeliness. It will be argued in the conclusion that these findings provide an important, hitherto neglected, perspective on how contemporary detention and removal practices, intertwined with global inequalities and colonial histories, are obscured and legitimised in everyday, localised and intimate, spheres in places beyond the vicinity of Haslar.

The article will first introduce Haslar and Southcreek, then the feminist geopolitics framework of the study and the fieldwork, before the empirical sections in which original data is presented. In March 2015, during the writing of this article, it was announced that Haslar IRC was to close, which it did with remarkable efficiency the following month. This came as a considerable and welcome surprise for many observers given the UK detention estate's tenfold growth in capacity over the previous two decades (Kaufman \& Bosworth 2013, 178). However, the conclusion will discuss potentially problematic implications of Haslar's closure in relation to the present study's findings in the broader context of recent UK policy developments and the Mediterranean migration crisis.

\section{Introducing Haslar and Southcreek}

Between 1989 and April 2015 as many as 190 men at any one time were detained in Haslar IRC (HMIP 2014, 7) as part of a UK detention estate that in 2013 processed over thirty thousand individuals (Home Office 2014). The explicit aims of the detention and removal system are unstated, 
though Bosworth (2014) argues that its core effect is to isolate and estrange detainees from broader society in preparation for deportation. Detainees have a bewildering variety of personal narratives and legal statuses, the latter including foreign national ex-prisoners, 'asylum seekers whose status is unclear, those whose asylum claims have been rejected, "over-stayers" and others in violation of Immigration and Asylum legislation', some of whom will have spent many years, possibly decades, of their lives in the UK (Bosworth 2008, 207). Just over half IRC detainees were removed from Britain in 2013, and around half at some stage claimed asylum (Home Office 2014). At the time of the last inspection in February 2014 the detained population of Haslar was overwhelmingly non-European in heritage, with $90 \%$ holding Global South citizenship, including many nations currently or recently wracked by armed conflict (HMIP 2014, 59). As Bosworth $(2014,50)$ suggests, 'the lingering effects of Empire remain visible in the disproportionate numbers of Commonwealth citizens held under Immigration Act powers', with the same inspection report finding that around $70 \%$ of those detained in Haslar originate from countries formerly under British imperial control or recently occupied by British forces (HMIP 2014, 59).

The treatment of those detained in the UK's removal centres varies considerably by institution. During the writing of this article alone, women detained in Yarl's Wood IRC alleged sexual abuse (Townsend 2014) and routine humiliation by male guards (Gentleman 2014); at Harmondsworth (Dutta 2014) and Dungavel (Davies 2015) IRCs male detainees were involved in hunger strikes in protest against conditions; and violent disturbances were reported to have taken place in Morton Hall IRC following the death of 26 year old detainee Rubel Ahmed in September 2014 (BBC Lincolnshire 2014). In informal discussions with detainees and immigration solicitors at the centre, Haslar seemed to be considered one of the better detention centres. However, no amount of positive measures taken within a centre can protect detainees from what Hall (2010) and Bosworth (2014) have demonstrated to be the daily uncertainties and insecurities of detention, fed in large part by the opacity and unpredictability of a legal system which produces an extremely stressful and traumatising experience.

Gosport, the town in which Haslar was located, has a population of eighty thousand and is situated on a peninsula between the cities of Southampton and Portsmouth on the south coast of England. Southcreek, on the south-eastern edge of the peninsula, is a suburb of Gosport primarily made up of detached and semi-detached houses as well as a small area of low-rise, primarily social housing flats. There are several open public spaces surrounding the residential areas, notably a golf course, a shingle beach, a seawall along the length of the IRC, and the nearby fields bordering Gosport Creek, 
the inlet separating Southcreek from central and northern Gosport. Like neighbouring Portsmouth, Gosport's topography is indelibly marked by historical and contemporary military fortifications due to centuries of association with the Royal Navy. These military links are today characterised by a mixture of heritage use on the one hand and working military function on the other. Haslar IRC itself was originally a naval barracks and then a juvenile offenders' institution before its conversion into an immigration detention centre in 1989. Nearby Fort Gilkicker, one of 'Palmerston's follies' built in the late nineteenth century as a defence against French invasion, is currently under stalled redevelopment into luxury flats, as is the IRC's direct neighbour, the derelict Royal Haslar Hospital, closed in 2009, where sailors wounded at the Battle of Trafalgar and numerous subsequent British military engagements were treated. The hospital's northern neighbour is a former submarine base, now a submarine museum, and just across from the road leading up to the IRC's entrance are the maritime testing facilities of a private sector arms manufacturer utilising former Royal Navy buildings. A few hundred metres west of Haslar, Fort Monckton serves as the Army's Secret Intelligence Service's field operations centre.

The militarised built environment of this part of Gosport, with its multi-layered relationships with centuries of British warfare, thus evokes Jonathan Meades' analysis of Portsmouth's topography as one that 'physically charts the history of British xenophobia... [It is] a monument to diplomatic failures, to the persistence of nationalism, to un-neighbourlines' (2004). Although Haslar IRC is not military run - it is operated by Her Majesty's Prison Service - when considering its militarised location and history, as well as the links between the majority of its detained population and the former British Empire, there are clear echoes of Bashford and Strange's $(2002,513)$ suggestion from the Australian context that contemporary immigration detention practices share a spatial and ideological heritage with the 'tortured and telling history' of colonialism (see also Flynn [2014] on the on- and off-shore, highly militarised and legally ambiguous anti-immigration measures, often involving former military bases, involving USA, Australia and EU governments).

Outside of the IRC, Gosport contains areas of considerable deprivation by British standards, though the suburban south of the town where Southcreek is located, with a population mostly made up of middle-class homeowners, falls into the least deprived fifth of English areas (DCLG 2010). Southcreek's population includes a disproportionately older and retired population, and the town has seen very little migration relative to many of England's urban areas, with $94 \%$ of Gosport classifying themselves as 'White British' according to the most recent census as compared to the wider English figure of 79\% (ONS 2011). When Haslar IRC was operational there were thus two 
starkly contrasting, spatially segregated populations in Southcreek - on one side of the fence, an affluent and overwhelmingly 'white' population living in freedom; and, on the other, an overwhelmingly 'non-white', detained population, many of whom were asylum seekers and amongst the most materially deprived individuals in Britain.

Prominent contemporary examples from elsewhere of similarly radically racialised and colonially inflected organisations of suburban space and population include the high degree of separation found in parts of the urban United States following the phenomenon of 'white flight' from the inner cities to the suburbs (Hartigan 1999, 10), as well as the 'fortified "white" suburbs' of post-Apartheid South Africa (Bremner 2010, 223-7). Even when setting aside such racially polarised examples, the kind of affluent suburban area exemplified by Southcreek is often framed by those living there and in the wider popular imagination - both in England, and more broadly in North Western Europe, North America and Australia - in relation to a normative, classed whiteness contrasted to inner-city and 'urban' areas associated with the undesirable and impoverished classed and racialised 'other' (Tyler 2003, 406-7). Recent research in both Australia and England finds that affluent, middle class 'whites' in suburban areas associate the figure of the 'asylum seeker' with a sense of racialised threat (Spinney and Nethery 2013, 186; Garner 2013), though in England evidence is also found to suggest that clear-cut associations between whiteness and the suburbs are being problematised by an increasingly multi-ethnic suburban population (Anon 2014).

When considering this introduction to Haslar and Southcreek, therefore, the fieldwork site has clear potential for the analysis of constructions of suburbia in relation to race, nationalism and the 'ongoing structures and cultures of colonialism' in Britain and more broadly the Global North (Jacobs 1996, 104). It invites analysis influenced by military geographies (Woodward 2005), and also of contrasting mobilities (Massey 1993) when considering lives separated by the IRC's fences. All of these approaches will play a part in the subsequent discussion, but what particularly emerges from the analysis are insights into how the seemingly mundane perspectives of those living in suburban Southcreek can be considered in relation to what Sundberg, drawing on Stoler, calls "'the intimate frontiers" of geopolitics' $(2008,871)$. The following section will introduce the theory behind this analysis. 


\section{Feminist Geopolitics and Immigration Removal Centres}

Feminist geopolitics scholars explore how global patterns and power-relations are 'reproduced in the mundane practices we take for granted' (Dowler \& Sharp 2001, 171). This approach refocuses how we consider scale by analytically 'binding everyday experiences' - at the level of the local, domestic and intimate - 'to wider networks' at the global, geopolitical level (Pain 2009, 10), with particular attention given to the 'inherent and unavoidable embodiment of geographical processes' (Dowler \& Sharp 2001, 169). Rather than the abstract, disembodied and implicitly masculinised perspectives of traditional geopolitical research and theory, nicely encapsulated by Koopman as 'Big men moving big guns across a big playing field' $(2011,274)$, feminist geopolitics opens up a clearing from which grounded, emplaced and (particularly female) embodied perspectives on 'power, oppression, and resistances [can be analysed] at and between multiple scales' (Massaro \& Williams 2011, 567).

Feminist geopolitics analyses therefore methodologically and analytically disturb the traditional categories, demarcated populations and boundaries of politics defined, for example, through nationalist discourse and practice. Whilst not downplaying the 'often bloody ramifications of militarised border zones on the ground' (Silvey 2006), an emplaced, intimate and multi-scalar analysis should displace 'attention on borders' onto those who cross, or do not cross, those borders (Hyndman 2012, 243), thus developing a 'politics of security at the scale of the (civilian) body' (Hyndman 2004, 309) rather than simply at the scale of the nation-state or geopolitical region. Relationships viewed in terms of their simultaneously global and intimate scales in this way can and do unsettle or 'transcend political borders' (Mountz \& Hyndman 2006), and an important element of feminist geopolitics analyses involves considering how the normative and bureaucratic categories and boundaries that serve to delineate in-groups from out-groups are formed in locally messy and ambivalent ways that often disrupt dominant interpretations.

In contrast to the present study, research involving migration and migrants influenced by feminist geopolitics often focuses on the marginalised or the traditionally under-researched. Examples include the exploration of the links between Cambodian women's localised and embodied reactions to enforced evictions spurred by geopolitical transformations (Brickell 2014), or Andersson's (2014) analysis of how clandestine migrants moving northwards through Africa towards Europe experience a somatisation of the border-zones they traverse. Other studies, however, such as those of Mountz (2004) and Sundberg (2008), focus on the quotidian, everyday negotiations and renegotiations of 
national space and boundaries in the 'receiving countries' of global migration. For ethical reasons and due to the transience of Haslar IRC's population it was not possible to speak to the detained population of Southcreek as part of the present project, so in speaking to affluent middle-class white 'Westerners' the present study echoes the latter studies' focus on those with relative privilege and power rather than those whose bodies are a site of suffering and relative powerlessness.

There is a danger that a study focusing on those 'outside' of Haslar may methodologically and analytically contradict the goals of feminist geopolitics by recreating the inside-outside binary of the IRC's fences normalised by nationalism and the infrastructure of the UK's removal system. To avoid this possibility, the present study aims to add to literature which takes IRCs as objects of inquiry but which also fundamentally problematises the boundaries of these institutions. Bosworth's (2014) key conclusion, from ethnographic research undertaken within six IRCs, is that they are 'sites of estrangement'. Detainees are estranged through their exclusion from wider society for the purpose of removal from Britain, but those employed in the centres, particularly IRC guards, are also found to be estranged from others, or from their own role within the centre, either through a dispassionate, sometimes cruel attitude towards detainees, or through feelings of confusion and distress relating to the mistreatment through border control processes of individuals with whom emotional ties and identifications have developed. Bosworth's analysis of the simultaneous and intertwining estrangement and alienation of detained and non-detained individuals within IRCs - contextualised in relation to racialised histories, global inequalities and contemporary global migration flows disrupts at the human level the categories and relationships imposed by nationalist, legalbureaucratic state structures, as well as demonstrating everyday examples of, and further potential for, 'thinking otherwise' about border controls $(2014,207)$.

The present research, focusing on the suburb bordering Haslar IRC, complements and expands on the studies of Bosworth and others undertaken within IRCs by providing a similarly critical and multiscalar analysis from without, keeping the inside and functions of Haslar in mind whilst critiquing the inside/outside distinction through a theoretical and analytical approach informed by feminist geopolitics. This article provides an original contribution to the study of IRCs through its focus on their surroundings, with the analysis that follows arriving at the potentially important conclusion that, for this study's participants, processes by which the boundaries of the IRC are obscured, legitimised and disavowed are fundamentally bound up with ideas surrounding place, home and intimacy. 


\section{Fieldwork}

In January 2014 I hand-delivered approximately four hundred letters to houses within Southcreek, all of which were within half a mile of the IRC. This invited participants to take part in interviews exploring their views on the local area, the place of Haslar in the area, and their wider views on immigration. Twenty five participants, thirteen men and twelve women, were interviewed including some joint interviews. The youngest participants were in their thirties, all with primary school age children, and over half were in their sixties or above, most of who were retired. In the context of the area's older population profile this was not a large imbalance, and the core patterns discussed below were found across all age groups.

All but one participant described their economic situation as comfortable and all were homeowners. There is thus also a middle-class skew to the sample, particularly as the small area of social housing flats was not accessible for the hand delivery of letters without the required security fob key. Given Southcreek's relative affluence this was again not unexpected or problematic. All participants identified as 'White British' and all but three have lived in Southcreek for over five years, with most living locally - within Southcreek, Gosport or Portsmouth - for all of their lives. The semi-structured qualitative interviews took place in participants' houses and lasted for between twenty minutes and three hours, with an average length of around one hour. Interviews began with discussions about Southcreek, how long participants have lived there and their views on the area, whether it feels like home, and if so why. Later questions asked what participants 'think about Haslar IRC', whether they would be interested in knowing more about or 'hearing the stories of' detainees, and about their general attitudes towards immigration.

The remainder of the article looks in detail at some of the key results emerging from a thematic analysis of the data produced. All participants' names have been changed as well as other identifying characteristics such as occupation, references made to workplaces, former places of residence, and so on, though in none of these instances is the overall character of the data significantly changed from the perspective of the analysis presented. 


\section{Perspectives on Southcreek}

This first findings section will analyse participant perspectives of suburban Southcreek before discussing these findings in relation to Haslar's function and detained population in a global context. Southcreek is portrayed by all but two participants in an unambiguously positive way. The most common, often immediate, response to the question of what participants 'think about' the local area is that it is 'nice'.

Stephen (seventies): It's a nice area.

Lloyd (forties): It's just a nice...area.

Alison (fifties): This is a nice part [of Gosport]... We have got...a nice little community here.

Caroline (thirties): It's awful the word nice isn't it, and it's just trying to break down what that means?... I just like the area.

The area and its inhabitants, either in terms of neighbours or, as Alison states, collectively in terms of 'community', are all described as 'nice'. Lloyd states that Haslar is 'just' nice and Caroline 'just' likes it - the word 'just' here suggesting an actuality and simplicity to these statements and feelings which seems to resist explanation. At the same time Caroline also reflexively suggests that this affection for the area can perhaps be broken down and explained in further depth, a process that most participants proceed to undertake. The most prominent explanation for this view of Southcreek relates to its suburban character.

Joseph (eighties): This area to me is ideal, it's idyllic... I think I've got the best of all worlds, because I class this as like semi-rural and semi-suburbia. It's in-between if [you] can understand what I mean... You've got the countryside and you've got the town and I'm in the middle.

Ruth (seventies): There's quite a sort of country feel about [the local area]. 
Caroline (thirties): [When she had lived in Portsmouth] there were just houses, whereas here...[although] there obviously are a lot of houses, there's a lot more greenery, there's a lot more open spaces, the houses don't seem to be so crammed in.

All participants link their affection for Southcreek to its topography and spatial organisation, particularly the open spaces, notably the sea, the local beach, and various public green areas. As seen in Joseph's excerpt, many participants portray Southcreek as idyllic in relation to this sense of openness, drawing clear associations with the rural, and thus evoking a particularly 'English' construction of suburbia (Anon 2014). No participant, however, suggests that they are not living in an urban area - as Ruth states, Southcreek only has a 'sort of country feel' - and this feeling of inbetweenness, blurring the boundaries between town and country, seems to help residents experience the most desirable elements of both. Participants particularly contrast Southcreek to the more built-up, compact urban living associated with neighbouring cities such as Portsmouth and with the less 'open', and more deprived, areas of central and northern Gosport.

The bridging of the rural and urban that Southcreek's geographical situation and topography makes possible is not only seen as desirable in abstract or aesthetic terms - though participants highly value the views from the shoreline of passing boats, ships and the Isle of Wight - but also figures as important in relation to everyday activities, particularly leisure activities involving the various open spaces. Green spaces, the sea wall, the beaches and the sea itself, all within a few hundred metres of each interviewee's house, are utilised for walking - often with a dog or two - running, fishing, swimming, playing golf, bowling and sailing. Most of the several retired participants with substantial amounts of leisure time on their hands, discuss social activities such as golf, sailing and water-colour painting, all pastimes largely associated with the middle-class. Leisure opportunities are also spoken of as a crucial part of the area for families with younger children, for whom the openness of the area is seen to provide a safe environment and suitable options for play and for the 'enriching' activities so important to normative middle-class parenting strategies (Vincent \& Ball 2007).

Indeed for many participants, regardless of age or life-stage, Southcreek is associated with, or even defined in relation to, families and family life. In the following excerpts Ben and Ray are answering the question 'what makes the area feel like home to you?', Ruth is discussing what she likes about the area generally, and Cath whether the area has changed in the years she and her husband have lived there. 
Ben (fifties): Friends and family [make the area feel like home]. We're very established here.

Ray (sixties): My children are around me, [and my] grandchildren, so yeah, it's comfort [that makes it home].

Ruth (seventies): It's very much a family place. There are a lot of extended families all round here, which is quite unusual nowadays, and that makes quite a nice atmosphere.

Cath (fifties): When we first moved in [to Cath and her husband's house, the previous owner of the house told Cath that] there's ten children in the road... As the years have gone by there's always been ten children in the road...there's about ten children still here, some of them are grandchildren... And then our grandson comes, so he's one of those now...so I wouldn't say [the area has] changed at all.

Proximity to family is seen as intrinsic to nearly all participants' perspectives on Southcreek, with some, such as Ruth, characterising the area itself and its population - again in relation to the word 'nice' - as 'a family place'. Ideas surrounding family are thus crucial for imagining Southcreek as a place that is homely both in terms of the individual participant's family circumstances and in relation to a desirable 'atmosphere' associated with a heteronormative social structure. Key to these perspectives are feelings of stability. Ben and his wife are 'established' and Ray feels 'comfort' in relation to local family. For Ruth the area is positioned as 'unusual' in terms of the continuity and settledness of its population, and similarly in Cath's excerpt, though individuals and families on the road on which she lives come and go, the family makeup and dynamic of the area, its familial continuity and stability, ultimately remains untouched. The feelings of stability and comfort participants associate with Southcreek as a place are thus in various ways enabled by the construction and experience of space in relation to notions of 'contemporary western domesticity' (Blunt \& Dowling 2006, 101) and particular, heteronormative notions surrounding family and society.

But whilst Southcreek is spoken of as a highly desirable place in which to live, convenient access to places beyond is also important. Central to many discussions is the ease with which participants can commute to work outside of Gosport, travel to supermarkets and other shops elsewhere in Gosport or in Portsmouth, and the relative convenience of accessing nearby cities or transport hubs, such as London, or Gatwick and Southampton Airports, as well as tourist destinations like the Isle of Wight 
or France, by car or by ferry. Though notions of familial roots and stability, and therefore relatively sedentary lifestyles, are central to participants' positive perspectives on Southcreek, the suburb is thus also placed in a wider geographical context enabling mobile, middle-class lives for which employment, consumerism and leisure options and opportunities beyond Southcreek and Gosport are a core concern. In contrast to potentially more isolated and confined lives, within socially and economically marginalised areas, Southcreek is seen by these relatively affluent, middle-class homeowners in relation to a 'spatial reach' extending beyond the 'contiguous neighbourhood' (Smith 1993 cited in Morley 2002, 197).

Taken together, the foregoing analysis suggests that, for the participants in this study, culturally and historically specific ideas about a desirable, homely place enable and are enabled by economic mobility and associated classed and heteronormative lifestyle options and familial norms. The same ideas and processes that contribute to these material and imaginary constructions of place and home are also implicated in the cultivation and enactment of normative ideas about the self and the organisation of society or community. It is perhaps the founding of these narratives of self and place in relation to implicit norms and subjectivities that explains why the 'niceness' of Southcreek is seen to resist analysis for participants; an outcome of which is an effective depoliticisation of what critical analysis finds to be particularly classed and normatively English constructions of a suburban place.

Prior to analysing participants' direct discussions regarding Haslar, the above accounts of Southcreek already suggest relationships between participants' perspectives, the IRC and detainees. It is first instructive to note the extreme contrasts between how suburban Southcreek life is discussed when held up to the literature exploring life inside IRCs. As Hyndman, drawing on Massey, argues: 'mobility is inherently political' $(2012,248)$. This study's participants discuss a wide range of mobilities available to and enacted by them, but anyone detained in an IRC, regardless of how embedded they are in British society, is incarcerated under threat of expulsion from British territory. In contrast to participants' accounts of holidays in continental Europe via aeroplane or ferry, many detained asylum seekers will have travelled long distances, sometimes in difficult and dangerous conditions, to get to Britain. Mobilities in Southcreek are thus variously marked by convenience and leisure or deprivation and stigma (Andersson 2014, 7). Contrasts can also clearly be drawn in relation to participants' feelings regarding stability, continuity and the family. Studies exploring IRCs (Hall 2010, Bosworth 2014) find, above all else, that detention and removal processes are responsible for a tremendous amount of anxiety and insecurity, with considerable pain and damage inflicted upon the body and psyche of detainees and those close to them, often particularly in relation to 
unexpected movement between IRCs (Gill 2009). Specifically in relation to families and children, IRC detainees are physically separated, at varying distances, from their loved ones, with their children's experiences of trauma well documented (Campbell, Boulougari, Koo 2013).

The above analysis barely touches the surface of the many contrasts that can be made when comparing this study's participants' perspectives on Southcreek to the angst-ridden, insecure situation of detainees discussed in the literature. These extreme contrasts should not, however, merely be argued as unjust in terms of abstract ethics or principles of human rights; they are, rather, the product of situations that are intimately related at local and geopolitical scales. Putting aside for a moment those in detention who do not consider themselves migrants, the potential financial success offered by migration to Britain and the Global North promises particular forms of 'selffulfilment and self-realisation' which then contribute to 'mounting economic, social, and cultural frustration' globally (Harvey 2000, 91). We can speculate that for many of those detained in Haslar it will have been precisely the kinds of mobility, employment, consumer and leisure opportunities and notions of a safe, stable family life discussed by this study's participants, all bound up with notions of a 'nice' and homely place, that will have motivated their migration to Britain. In this context, the IRC infrastructure plays a crucial role in border controls and regulating membership of the nation-state by preventing migration and settlement of individuals drawn from amongst the world's most deprived states whose migration is provoked by global inequalities and/or conflict. Britain, the Global North, and militarised Southcreek specifically, are all implicated in these inequalities and conflicts in complex ways, historically through colonialism (Davis 2002, Lange 2004) and more recent wars, and in relation to the stability and comparative affluence of the UK economy within a geopolitical economic structure vastly favouring the Global North (Amin 1976, Andersson 2014, 19). IRCs such as Haslar are thus an important mechanism by which the material privileges enjoyed by many British citizens, described locally by this study's participants, are denied to and protected from those, largely 'non-white' individuals, deemed 'other' to the nation.

Participants' seemingly mundane perspectives on the suburban area of Southcreek can therefore be revealingly interpreted by an analytical rescaling that brings into focus the area's position within a web of complex social and power-relations involving global and racialised inequalities, migration flows and nationalism. What may at first glance seem like radically divergent, spatially related but separate, situations either side of Haslar's fences should instead be thought of in relation to collectively and intimately experienced geopolitically significant relationships spanning the IRC's boundaries. 
However, putting aside the localised comparison provided by Haslar's presence, this analysis could be applied to the positive portrayal of many other English suburbs similar to Southcreek that do not border an IRC. The following section will demonstrate that during direct discussion of participants' perspectives on Haslar IRC and those within its walls we see some ways more specific to Southcreek by which the global, the local and the intimate are bound together.

\section{Southcreek and Haslar IRC}

When answering the question 'What do you think about Haslar Immigration Removal Centre?' all but one participant refers to an absence.

Joseph (eighties): You wouldn't think there was a removal centre here...it's an establishment that is out of sight and out of mind

Norman (sixties): It's invisible, you know, nothing.

Lloyd (forties): If we go for a walk, you can go down the side of Haslar and walk out onto the seawall...it's not in the consciousness.

Sue (fifties): Until your letter came, I have to be absolutely honest, I hadn't even given it a thought.

Thomas (sixties): To be honest....when your thing [letter] came through and I was talking to [my daughter] to be honest I don't even think about it. I mean you don't even know it's there.

David (fities): It's just there, you don't think about it.

Alison (fifties): It's just there... It's like a blank canvas sort of thing.

For most of these participants Haslar is spoken of as if it is entirely absent from their view, consciousness or thoughts. For David and Alison the centre is spoken of in a way that suggests it is 
visible, that they at least see it, but also in a way that suggests it is not considered or reflected upon - it is 'just' there, in actuality, in the background. Several participants elsewhere explain this absence of reflection in relation to the wider area's militarisation, most notably as a result of the high walls, fences and closed-off areas characteristic of this part of Gosport - as David suggests, shortly after the above excerpt, 'there's no difference round here, [as] one place looks like....another'. Woodward has demonstrated that the local presence of the military is often a simultaneously 'prosaic and profound issue', with its 'warring and violent infrastructure' routinely taken for granted within the built environment and landscape $(2005,728)$. For the participants in this study, we see a similar process of backgrounding for Haslar and its neighbouring militarised spaces and institutions, each of which, like the IRC itself, has been or remains involved in the forcible, often violent maintenance or expansion of the nation-state's boundaries.

However, whilst initially suggesting that they never see or consider Haslar, when asked whether the IRC has 'any effect' on them, participants did discuss the institution, building and site in relation to their everyday lives and concerns. Lucy and George took part in a joint interview.

Elizabeth (seventies): I feel more secure knowing that...my house is being kept an eye on [by Haslar's CCTV cameras].

Norman (sixties): The parking's a problem [around Haslar]...because of all the workers and visitors parking, all the lawyers and things.

Sue (fifties): I was concerned on the land-buy at the [Haslar] car park...that they were planning to build houses there... But we like [Haslar]. I mean I walk him [the pet dog] down there [to the seawall side of Haslar], especially in the summer.

Lucy (sixties): I love it here, I love the view [from the upstairs window of the sea], I don't mind the barbed wire [which is part of this view]. It's quiet, it's peaceful, l'd rather have an immigration detention centre than a housing estate... Yeah, so, quiet neighbours.

George (sixties): They are really [...] And security wise it's also a good thing for us [in relation to CCTV]...so all in all [Lucy talks over George]. 
Lucy: I think it's positive.

George: It's a positive thing, yeah it is.

Norman is concerned with parking, Elizabeth and George are concerned with their property's security, and Sue is concerned about the potential for the development of land adjoining the centre. Although many of the essential component parts of the detention system - lawyers, CCTV and barbed wire - are mentioned, they are distanced from the centre's core carceral and expulsionary functions. Lawyers become a parking nuisance, cameras aimed at keeping detainees incarcerated are related to personal security assurance, and barbed wire disappears in relation to a sea view. As Sue, Lucy and George demonstrate, Haslar is even spoken of as a positive part of the area due to the walks surrounding it and thanks to the predictability and stability of having an incarcerated population for neighbours. These and other participants' overriding views on Haslar thus directly relate to the kinds of constructions of Southcreek-as-place, and attendant secure, stable, comfortable and leisured lifestyles, analysed in the previous section. The coercive infrastructure experienced by those within Haslar is here transmogrified into an unseen, banal or positive part of the landscape. Southcreek's militarised, historical and ongoing, associations with key mechanisms for enforcing nationalist and racialised social and spatial organisation at simultaneously local and global scales, are thus mundanely obscured, along with the individual lives of detainees, in relation to the taken for granted local built environment and participants' lives within this environment.

This routine obscuring of Haslar and its function is, however, revealingly disrupted in relation to the question of whether participants would be 'interested in hearing the stories of the people in Haslar?' The following excerpts are from interviews with George (interviewed with his wife) and Thomas, both of whom express strongly anti-immigration views throughout their interviews, stating on a number of occasions that they know and care little about those detained within the IRC.

George (sixties): Erm [pause followed by laughter from him and his wife]. I think I'd tend to feel rather sorry for them all and be a soft touch, I think that's the only trouble.

Thomas (sixties): I think the trouble is once you start to hear the stories... [and] they've got a bad story to tell...if you're not careful you...say 'oh right, well of course you can come in'...and before you know it you've opened the floodgates to everybody coming in, and...unfortunately you can't do it, it's a small country... 
CLO: So talking to them, you're worried that you would become too emotional...too sympathetic?

Thomas: Yeah that's the trouble. You...would become too emotional about it, and I think unfortunately you've got to be hardnosed.

Following what seems to be nervous laughter George suggests that the prospect of encountering detainees would be discomforting as he would be affected by pity to the extent that he would become too emotional and thus vulnerable to them - he will, he fears, become 'a soft touch', suggesting an implicitly feminised vulnerability (Ahmed 2004, 2). Thomas similarly suggests that hearing the individual stories of those who are detained in Haslar would be problematic as it might provoke greater sympathy and empathy with their situation, one implication being that each individual could be considered as having the right to live in Britain. Both participants share concern for the potential 'trouble' that might emerge if emotional contact were to soften their views, expressing anxieties about what the costs of connecting with detainees would be for them emotionally, thus effectively and affectively inverting the power-relationship between citizen and detainee - here fears felt 'within' the individual in relation to the prospect of intimacy are intertwined with nationalist discourses surrounding the vulnerability of a population to the threat of immigration (Ahmed 2014, 25). These anxieties are, however, mediated for Thomas through the invocation of 'hardnosed' nationalist rationalities aimed at protecting this 'small country' and through which the potentially troubling implications of emotional connection are disavowed.

Many other participants responded similarly in relation to anxieties surrounding the prospect of intimacy when asked directly about Haslar's function and detainees. Caroline (thirties), for example, argues for the necessity of efficient detention and removal processes as it is impossible to think of every individual circumstance without 'going mad', and Lloyd (forties) suggests that whilst his views on not wanting to hear the stories of detainees might 'sound callous', it is more appropriate to entrust all personal contact and responsibility to 'the system' processing them. When leaving his house Lloyd stopped me to make a final point off tape, suggesting that a greater involvement of detainees in Southcreek outside the centre might 'unbalance' and damage a local area for which he holds great affection. He seemed worried that my research might lead to such an outcome and gave the impression that he was warning me off any work towards such an end. 
In contrast to reflections on the local area and the site and institution of Haslar, in the moments where the potential for actual intimacy with detainees is being discussed and imagined the hitherto routine drawing of nationalist and geopolitical boundaries becomes a messier emotional process in relation to guilt, anxiety and fear. Despite this messiness, these boundaries are still, however, drawn. This is achieved by positioning the suburban resident as emotionally vulnerable, or - in a way that is more emotionally satisfactory for the participant - in relation to a disavowal of political and affective connection and responsibility in favour of the 'hardnosed' rationalities of 'the system' (which only 'sound callous'). Through this latter process of disavowal in particular, the construction of boundaries and the reflections on the individuality of detainees raised by the prospect of intimacy become increasingly depersonalised and abstracted. These participants effectively delegate their relationships with detainees, and any emotional, ethical and political responsibility, onto the disembodied rationalities and mechanisms of the nation-state.

This pattern of disavowal will be analysed in further detail below, but it is first useful to discuss how these boundaries and rationalities are more thoroughly reassessed by two further participants, Sue and Cath. For most of the interview involving Sue and her daughter Jess, Sue expresses views that are highly critical of asylum seekers who she associates with welfare dependency. However, towards the end of the interview Jess, a social worker, discusses her experiences of working with asylum seekers and the trauma of the asylum process for families who are separated by the detention of parents whilst children are taken into state care. This account visibly shocks her mother.

Sue (fifties): I've never given it any thought... I feel really awful now, living...on the doorstep [of Haslar] and not knowing anything.

Jess (thirties): I think it's easy for us to make judgements...but we don't know what these people have gone through...

Sue: I feel so guilty [pause]. It's terrible [pause]... I've certainly been very naïve.

Reflections on children and families, so important to most participants' constructions of Southcreek as a homely, secure area, are particularly disturbing for Sue. She suggests that she now 'feels awful' about having people going through the kinds of traumas her daughter has described as neighbours. Here the experiences of detainees come into view - clearly contrasting to the same participant's earlier excerpt portraying Haslar primarily as a good place for dog-walking. By making links between 
her daughter's account of the lives of asylum seekers and Haslar's location on her 'doorstep', the relationship between suburban Southcreek and the enforcement of ethically questionable border control practices is unobscured through feelings of guilt and shame.

A similar pattern can be found with Cath, who demonstrates more empathetic concern with detainees than other participants, seemingly due to a greater knowledge of the IRC gained through personal contacts with volunteer visitors and former detainees. Cath also demonstrates views that are highly critical of wider attitudes towards migration, arguing at one stage that anybody, including those within Haslar, has as much right to live in Britain as she does. Nevertheless, until the following excerpt, Cath's account echoes other participants in suggesting that, during her daily life in Southcreek, Haslar and its function never enters her consciousness.

Cath (fifties): When you were asking me to define this [area] as our home...[what] we've [Cath and her husband] always liked is the freedom and the openness. And...that's directly opposite to these people who are living in Haslar... We are living here next door to these people who have got no freedom at all...but I've never thought of it in that way. They ought to be free to enjoy what we enjoy... That's not right.

Cath directly contrasts her and her husband's constructions of Southcreek as homely earlier in the interview with the situation of those in Haslar. This is particularly linked to the sense of freedom and enjoyment she associates with the area's openness. These reflections, no doubt partly founded upon her political convictions, thus provoke an argument in which the extreme disparities of freedom and lifestyle either side of the fence, and the power-relations they are reliant upon, are portrayed as unfair in relation to equal rights - a position rejected by Thomas and others as we have seen - and in relation to the detainees' situatedness in the place that Cath considers homely. In both Sue's and Cath's excerpts the people within the fence are thus considered in a way by which, in stark contrast to other participants, their relationship to Southcreek is recognised and embodied - as another participant suggests, when reflecting on the lives of detainees they can 'become somebody, not just a fence' - and this specifically happens through a reassessment of spatial and affective proximity.

The enforced separation of detainees from the rest of Southcreek is here, in Sue's and Cath's reflections, foregrounded in a way that ethically problematises Haslar and its function, thus effectively breaching the political legitimacy of the IRC's fences. Crucially, for both participants, this process involves the disturbance of the idea of Southcreek as a homely place, with each participant 
anxiously reassessing their relationship with the local area. Žižek suggests that the 'illegitimate violence by which law sustains itself must be concealed at any price' as we 'cannot at one and the same time assume the historical origins of the law in some lawless violence and remain its subjects' (1991, 204; 205. Original emphasis). Sue and Cath demonstrate that, if the anxieties raised by the potential for intimate and emotional connections with detainees are not disavowed and rationalised away in relation to the nation-state, it can become more difficult to imagine Southcreek, and oneself within Southcreek, in an affectively and ethically satisfactory way. For these participants, the very personal, emotional and embodied, sense of discomfort that comes with living in an area marked by such extreme inequalities disturbs the homeliness of this area and, at least momentarily, the legitimacy of the nationalist and geopolitical boundaries effected by Haslar IRC. The implications of this pattern will be discussed in the final section.

\section{Discussion and Conclusion}

As Woodward suggests: 'Things that seem mundane are often protected by their ordinariness from critical gaze. The most interesting stories lie in the connections between many seemingly small things that build a bigger picture, revealing networks' $(2005,731)$. An analysis treating the global scale as bound together with the spatial, 'embodied and sensory practices' described by Southcreek's suburban residents can highlight the ways that these participants' accounts 'bleed across, resonate through, and fundamentally blur the spatial, temporal and ontological distinctions' (McSorley 2014, 122) that, when merely taken for granted, serve to normalise the separation of lives on the inside and outside of Haslar IRC's fences. In an area with long-term and ongoing associations with the military, the apparently mundane middle-class suburban emplacement and daily lives of Southcreek's free population have been argued above to be structurally implicated in colonial histories and in Global North privilege which remains significantly reliant on the deprivation of the Global South. The radical contrasts between detainees' experiences and participants' mobilities, leisured lifestyles and feelings of stability, as well as the brute fact of a $94 \%$ 'white' population living in freedom next door to a $90 \%$ 'non-white' detained population, are therefore not merely unjust from an abstract political perspective concerned with inequalities and rights; they are, rather, the product of long-standing inequalities and discrimination which are fundamentally implicated in the everyday lives of each resident of Southcreek. 
By drawing on feminist geopolitics insights, and by thus considering different scales simultaneously, the divisions and power-relations enforced by Haslar's fences are symbolically and politically breached by the very different but collective experiences of Southcreek's free and detained residents. For those on the free side of the fence it is particularly the prospect of intimacy which provokes an insecure and anxious emotional reassessment of their understandings of Southcreek which, through the obscuring of the IRC's function, are otherwise confidently put forth as simply 'nice'. Therefore if participants' normative feelings about the local homely area are to remain coherent then the disavowal of discomforting knowledge and emotions relating to Haslar's detainees - and implicitly to localised relationships with colonial histories and global inequalities must be incorporated into their constructions of both self and place. The incorporating of this disavowal has been demonstrated to involve recourse to nationalist rationalities with disembodying effects by which relationships and potential emotional connections between participants and detainees are delegated onto the figure of the nation-state. This process legitimises the homeliness of Southcreek by managing and taming the feelings of anxiety and guilt that otherwise threaten to politically and emotionally blur dominant nationalist and geopolitical boundaries and hierarchies for participants. A binding together of anxieties and their renunciation thus becomes internal to, and even a strength of, the process of everyday boundary construction through the containment of potentially troubling reflections on intimacy, political morality and ideals of inclusion (in a manner echoing Brown's [2006] critique of discourses of tolerance that ultimately reiterate processes of 'othering').

The strength of this pattern becomes apparent if we consider that, for most participants, the disavowal of associations with local and global inequalities, and implicitly with intertwining colonial histories, does not lead to melancholic, explicitly aggressive or hostile racism, or even to particularly strident expressions of nationalism (as Gilroy [2004] recounts). It leads, rather, to a relatively subtle (from their perspective at least) and abstracted, bourgeois and domesticated, concealing of global and local white privilege and racialised segregation. The analysis above therefore finds a quiet, contemporary suburban counterpoint to highly durable racialised formations and violence rooted in British and European colonialism; and this very quietness is (to varying degrees of conscious intentionality) strategically essential if the fundamentally racialised temporal, material, infrastructural and spatial interrelationships emplaced and embodied in Southcreek are to remain obscured, and thus politically and morally justified, for those they privilege. Sue's and Cath's reflections, in contrast, demonstrate hope at least for an acknowledgement and working-through of the political, emotional and ethical implications of the nationalism, contemporary geopolitics and 
colonial histories of which Haslar IRC and its militarised surroundings are symptomatic. The recognition by these participants that nationalist power-relations are violently inscribed onto Southcreek through the incarceration of individual, embodied detainees is bound up with their own anguished, embodied responses. Their feelings about the local area are thus transformed through the 'emotional conditions' (Pain 2009, 15) produced by a collision between, on the one hand, the sense of affection and homeliness felt in relation to suburban Southcreek, and on the other, the norms of intimate sociality and principles of equality and freedom that they come to consider as being violated locally by Haslar.

The closure of Haslar in March 2015 raises the question of whether these findings would be repeated today, or in a year's time. We might speculate that, despite the absence of an IRC in Southcreek, many patterns would be similar. Indeed, I would argue that much of the above analysis of affective and emplaced patterns extends far beyond the environs of Haslar and would be found among many residents of 'white', affluent British suburbia for whom border control processes are obscured. Although exemplary because of remarkable, perhaps unique to Britain, associations with border controls and the military, Southcreek's residents' relationships with migration, warfare and colonialism are potentially broadly similar, in terms of underlying contexts and histories as well as present attitudes, to residents of other British suburban areas not immediately proximate to military bases or IRCs. In terms of future research and activism regarding Britain's IRCs, a conclusion of this analysis is therefore that the detention and removal regime will never be fundamentally challenged unless we engage with the complex ways in which many of society's most privileged are mundanely, affectively and intimately (and usually only implicitly) invested in the same geopolitical, nationalist and racialised norms foundational to coercive border controls.

What I think a site directly neighbouring an IRC does uniquely provide, however, through sheer spatial proximity, is a greater opportunity for the imagining of detainees. As the previous section demonstrates, interview questions founded upon proximity and potential intimacy helped to produce some of the most interesting data and analysis, leading to the article's key original conclusions. It is unclear whether, without the presence of detainees a few hundred metres from where the interviews took place, the sense of anxiety and guilt, the fears about detainee involvement in the local area, or the sense of unhomeliness that arose from reflections on localised and embodied inequalities and injustice, would have emerged from participant discussions. 
This is an important point for the findings of the present paper but also in broader political terms. At the time of writing, summer 2015, the recently elected Conservative government is attempting to make even the prospect of this kind of relative proximity more difficult. If the manifesto commitment of extending the 'deport first, appeal later' rule (Conservative Party Manifesto 2015, 30 ) is honoured then the removal process will be streamlined - an aim which perhaps helps to explain the surprise closure of Haslar and the decision not to pursue the extension of Campsfield IRC (BBC Oxford 2015). The government is also steadfastly refusing to allow into Britain any of the hundreds of thousands of refugees crossing from North Africa to Europe, instead lobbying with some success for the EU to adopt a primarily militarised approach, inspired by similar US and Australian off-shore strategies (Flynn 2014), which aims to strike at traffickers in North Africa and to cooperate militarily with African states in the instalment of border controls and camps outside of Europe (Traynor 2015, McVeigh 2015). This increased distancing and abstraction of global inequalities from Britain and Europe may thus render the likelihood of reflections on the intimacy of geopolitical frontiers similarly more distant. Whilst IRCs are 'sites of estrangement... where the ties between those within and those outside are cut' (Bosworth 2014, 221), their current situation within Britain at least provides potential for intimacy, imagined or otherwise, and thus also for the troubling of this estrangement. If Britain is to attempt to close its borders to those most adversely affected by global politics then an effective refocusing of traditional geopolitical scales for those within Britain, particularly those living in affluent suburban areas perceived by their residents as especially removed, becomes a more urgent task for those concerned with social justice.

\section{References}

Ahmed S, 2004 The cultural politics of emotion (Edinburgh University Press, Edinburgh)

Ahmed S, 2014 "Not in the Mood" New formations: a journal of culture/theory/politics 82 13-28.

Andersson R, 2014 Illegality, Inc: Clandestine Migration and the Business of Bordering Europe (University of California Press, Oakland)

Amin S, 1976 Unequal development: An essay on the social formations of peripheral capitalism (Monthly Review Press, London)

Bashford A, Strange C, 2002, "Asylum-Seekers and National Histories of Detention" Australian Journal of Politics \& History 48(4), 509-527.

BBC Lincolnshire, 2014, "Morton Hall Immigration Centre Disorder Investigated" 7 September rhttp://www.bbc.co.uk/news/uk-england-lincolnshire-29094137 
BBC Oxford, 2015, "Campsfield House Immigration Centre expansion plan shelved" 12 March http://www.bbc.co.uk/news/uk-england-oxfordshire-31851365

Blunt A, Dowling R, 2006 Home (Routledge, London).

Bosworth M, 2008, "Border control and the limits of the sovereign state" Social \& Legal Studies 17(2) 199-215.

Bosworth M, 2014 Inside Immigration Detention (Oxford, Oxford University Press).

Bremner L, 2010 Writing the city into being: essays on Johannesburg, 1998-2008 (Johannesburg, Fourthwall Books).

Brickell K, 2014, "The Whole World Is Watching": Intimate Geopolitics of Forced Eviction and Women's Activism in Cambodia" Annals of the Association of American Geographers 104(6) 1256-1272.

Brown W, 2009 Regulating aversion: Tolerance in the age of identity and empire (Princeton University Press, Princeton).

Campbell S, Boulougari A, Koo Y, 2013 "Fractured Childhoods: The separation of families by immigration detention" Bail for Immigration Detention Report (Marstan Press, London).

The Conservative Party Manifesto, 2015 A Brighter, More Secure Future (Conservative Party, London).

Davies C, 2015, "Religious and Refugee Groups Denied Access to Dungavel Immigration Centre" The Guardian 21 April http://www.theguardian.com/uk-news/2015/apr/21/religious-andrefugee-groups-denied-access-to-dungavel-immigration-centre

Davis M, 2002 Late Victorian holocausts: El Niño famines and the making of the third world (Verson, New York).

DCLG (Department for Communities and Local Government), 2010 English Indices of Deprivation (DCLG, London).

Dowler L, Sharp J, 2001, “A feminist geopolitics?” Space and Polity 5(3) 165-176.

Dutta K, 2014, "Asylum Detainees Stage Hunger Strike over poor treatment" The Independent 4 May http://www.independent.co.uk/news/uk/home-news/asylum-detainees-stage-hungerstrike-over-poor-treatment-9322812.html

Fishwick B, 2015 "Concern for jobs as Gosport immigration centre to be turned into prison" The News 26 March http://www.portsmouth.co.uk/news/business/local-business/concern-forjobs-as-gosport-immigration-centre-to-turn-into-prison-1-6655160

Flynn M, 2014 "How and Why Immigration Detention Crossed the Globe" Global Detention Project Working Paper Series (Global Detention Project, Geneva). 
Garner S, 2013, "The racialisation of asylum in provincial England: class, place and whiteness" Identities 20(5) 503-521.

Gentleman A, 2014 "Female detainees at Yarl's Wood routinely humiliated, claims report" The Guardian 14 January http://www.theguardian.com/uk-news/2015/jan/14/female-detaineesyarls-wood-report-privacy-immigration-detention-centre-sexual-abuse

Gill N, 2009, "Governmental mobility: The power effects of the movement of detained asylum seekers around Britain's detention estate" Political Geography 28(3) 186-196.

Gilroy P, 2004 After empire: melancholia or convivial culture? (Routledge, Abgindon).

Hall A, 2010, “These people could be anyone': Fear, contempt (and empathy) in a British Immigration Removal Centre" Journal of Ethnic and Migration Studies 36(6) 881-898.

Hartigan J, 1999 Racial situations: Class predicaments of whiteness in Detroit. (Princeton University Press, Princeton).

Harvey D, 2000 Spaces of hope (University of California Press, London).

HMIP (HM Inspectorate of Prisons), 2014 Report on an unannounced inspection of Haslar Immigration Removal Centre (HM Inspectorate of Prisons, London).

Home Office, 2014 Tables for Immigration Statistics Jan-March 2014 (Home Office, London).

Hyndman J, 2004, "Mind the gap: bridging feminist and political geography through geopolitics" Political Geography 23(3) 307-322.

Hyndman J, 2012, "The geopolitics of migration and mobility" Geopolitics 17(2) 243-255.

Jacobs JM, 2002 Edge of empire: Postcolonialism and the city (Routledge, London).

Kaufman E, Bosworth M, 2013, "Prison and national identity: Citizenship, punishment and the sovereign state" in Why Prison? Ed. David Scott (Cambridge, Cambridge University Press) pp. 170-188.

Koopman S, 2011, "Alter-geopolitics: Other securities are happening" Geoforum 42(3) 274-284.

Lange MK, 2004, "British colonial legacies and political development." World Development 32(6) 905-922.

Massaro VA, Williams J, 2013, "Feminist geopolitics." Geography Compass 7(8), 567-577.

Massey D, "Power-Geometry and a Progressive Sense of Place", in J. Bird, B. Curtis, T. Putnam, G. Robertson, L. Tickner (eds.) Mapping the Futures: Local Cultures, Global Change (Abingdon, Routledge) 59-69.

McSorley K, 2014, "Towards an embodied sociology of war." The Sociological Review, 62(S2) 107128. 
McVeigh T, 2015, "EU states in 'deals to shut African borders'" The Guardian, 13 June http://www.theguardian.com/world/2015/jun/13/un-fears-eu-secret-eritrea-deals-close$\underline{\text { border }}$

Meades J, 2004, "Portsmouth Dockyard" Abroad Again in Britain, Episode 3, broadcast on BBC2, 18 August 2004, retrieved from YouTube.com.

Morley D, 2002 Home territories: Media, mobility and identity (Routledge, London).

Mountz A, 2004, “Embodying the nation-state: Canada's response to human smuggling. Political geography" 23(3) 323-345.

Mountz A, Hyndman J, 2006, "Feminist approaches to the global intimate" Women's Studies Quarterly 1/2 446-463.

ONS (Office for National Statistics), 2011 "Neighbourhood Statistics" webpage, http://www.neighbourhood.statistics.gov.uk/dissemination/

Pain R, 2009, "Globalized fear? Towards an emotional geopolitics." Progress in Human Geography 33(4) 466-486.

Silvey R, 2006, "Geographies of Gender and Migration: Spatializing Social Difference." International Migration Review 40(1) 64-81.

Spinney A, Nethery A, 2013, "'Taking our Houses": Perceptions of the Impact of Asylum Seekers, Refugees and New Migrants on Housing Assistance in Melbourne'. Social Policy and Society 12(02) 179-189.

Sundberg J, 2008, "'Trash-talk' and the production of quotidian geopolitical boundaries in the USAMexico borderlands" Social and Cultural Geography 9(8) 871-890.

Townsend M, 2014, "Serco whistleblower's Yarl's Wood sex claim" The Guardian 24 May, http://www.theguardian.com/uk-news/2014/may/24/serco-whistleblower-yarls-woodpressure-immigration.

Tyler K, 2003, "The racialised and classed constitution of English village life" Ethnos: Journal of Anthropology 68(3) 391-412.

Traynor I, 2015, "EU draws up plans for military attacks on Libya targets to stop migrant boats The Guardian, 10 May http://www.theguardian.com/world/2015/may/10/eu-considers-militaryattacks-on-targets-in-libya-to-stop-migrant-boats

Vincent C, Ball S, 2007 “'Making up' the middle-class child: families, activities and class dispositions" Sociology 41(6) 1061-1077.

Woodward R, 2005, "From Military Geography to militarism's geographies: disciplinary engagements with the geographies of militarism and military activities" Progress in Human Geography 29(6) 718-740. 
Žižek S, 1991, For they know not what they do: Enjoyment as a political factor (Verso, London). 